\title{
Ann Brysbaert
}

\section{Forces of the hands, forces of the lands.}

\section{An awareness of people's multi-tasking in the agrarian and economic landscape of the Late Bronze Age Argive Plain}

Energy-spending is part of people's every-day lives.
This paper investigates how Late Bronze Age people in
the Aegean achieved their daily tasks and building on
a monumental scale while remaining resilient during
crises around 1200 BCE. Energy-spending resides in
active and pro-active strategies and shows the remarkable
resilience of people during potentially adverse times. It
seems though that, on the basis of currently available
data, agricultural activities took centre stage over all
other energy-spending tasks because of its sheer scale.

Energy, used in constructing past monumental building projects, refers to energy-spending as part of people's every-day lives. In focusing on energy spent by humans and other animals in labouring in prehistoric times, this paper investigates how Late Bronze Age (LBA) people achieved their multiple daily tasks while remaining resilient during multiple crises around 1200 BCE. ${ }^{1}$ Veritable building programmes took place since the fourteenth century $\mathrm{BCE}$ and resulted in awe-evoking citadels, burial monuments, waterworks, roads and bridges. ${ }^{2}$ These programmes must have mobilized substantial labour forces over sustained periods of time. Since agriculture and animal husbandry were the predominant subsistence strategies for most people in the Aegean LBA, such intensive and prolonged building efforts requiring a consistent amount of human and material resources, may have affected local economies profoundly. Some scholars have expressed the detrimental nature of mobilizing these work forces (resource exhaustion) to the sustainability of the socio- political structures toward c. $1200 \mathrm{BCE}{ }^{3}$ The human impact on dwindling resources, and also climatic changes have been seen as contributors to the Mycenaean socio-political collapse. Despite such 
attempts to explain the Mycenaean LBA crises or even 'collapse' c. 1200 BC in these terms, the extremely complex nature of many impacting factors causing these societal upheavals is still poorly understood. Equally, the factors which caused the 'collapse' itself are hotly debated. ${ }^{4}$ The hypothesis that massive building programmes were detrimental to the LBA Mycenaean societies, who carried out the work, deserves thus to be revaluated even though it is likely that each region in the Aegean and beyond suffered case-specific internal features. Exactly because of the complex role that such building programmes may have played in the Mycenaean society, and specifically in the Argive Plain, it is essential to investigate several combined factors of this prehistoric crisis and the specific role of prolonged building as one of these potential factors.

The SETinSTONE project, held at the Faculty of Archaeology and directed by the author, assesses if and how monumental building activities in the LBA Argive Plain impacted on the political and socioeconomic structures of the Mycenaean polities in the period between 1600 and $1100 \mathrm{BCE}$, and how people responded to changes in these structures. An energetic approach to this question aids to understand how humans and their supportive resources could have achieved long-term and large-scale building alongside many other tasks in the thirteenth century BCE, and how multiple levels of mobility of people with their skills, knowledge, animals, and materials in their surroundings were part of these energy flows. Impressive constructions were carried out already since the fourteenth century BCE. ${ }^{5}$ But what were the minimum resource requirements? Did these deplete resources towards $1200 \mathrm{BCE}$, and if so, to which degree? How did people within their short life span combine such work within the rhythm of other daily tasks? ${ }^{6}$ And which energy-saving strategies did they employ to cope with crises and work-pressure? Energy-spending here is found in active (producing) and pro-active (planning ahead) strategies and shows the remarkable resilience of people during potentially adverse times. Having combined the results of monumental building, domestic house building and pottery production for the entire region, on the one hand, with people's agricultural activities, on the other, it becomes clear that the latter are far more labour-intensive despite the scale of the other production processes and practices studied here. Without having the final results yet on all production lines that people were involved in, it seems that the activities of building on several scales and pottery production combined cannot be seen as detrimental to society around $1200 \mathrm{BCE}$. 


\section{Multiple methodologies}

In approaching the building efforts, architectural energetics based on detailed chaînes opératoires is a useful measuring tool and calculates the expenditure of human and animal energy extracted from calculating the masses and volumes of building materials. ${ }^{7}$ These latter are used to calculate cost-estimates per construction task per material and are then combined with the invested labour time-units, expressed in person hours/days/years. Even at this level, such number generation reflects a social construct since energy is dependent on the living beings that carry out the work: skilled and unskilled people, and their well-cared for animals, and between whom there is a co-dependent relationship of trust: in strength, capacity, care, and guidance. While fairly new in the Aegean, ${ }^{8}$ the method knows wide applications in many other settings. ${ }^{9}$

If we are prepared to see crafting in its widest sense, i.e. working with raw materials into making and shaping products, independent of scale, material and activity, cross-craft interactions ${ }^{10}$ are present everywhere and form nodes of energy flows that cross each other at multiple intersections, in processes of making at all possible levels. This notion resounds closely to Ingold's taskscape ${ }^{11}$ as every task undertaken is done in relation to others working together - within the community, and while people were looking after each other. These multiple energy flows touch on both the physical and social dimensions of making and being together in an aggregate of daily tasks to be done. ${ }^{12}$ Levels of physical energy input range from a child helping in collecting berries and branches in woodlands to a strong builder hoisting up full buckets of earth up a wall. Production processes are co-dependent and may result in knowledge and skill transfer and intersection through people's daily experience-sharing. Many examples illustrate this: using animal-drawn sledges for threshing and for transporting large blocks; and terrace-making and road construction on slopes. These cross-over actions impacted socially and technically on each other and their productions, and the people involved in these cross-over tasks transmitted skills through generations (vertically) and to newcomers and peers (horizontally).

Relative energy expenditure expresses, in a comparative way, the respective levels involved in both domestic house-building and monumental structures (see below). However, without at least a suggestion of the ranges of absolute figures it is impossible to understand the potential impact of such works beyond the individual and local levels. Domestic house building 


\section{Brysbaert}

obviously takes less effort per unit and the decision-making process of what to build, how big, with which materials, and where to take those from likely lies mostly with the household itself. ${ }^{13}$ Such work could probably also wait if more pressing issues need to be prioritized. We look at a very different scale when studying the Mycenaean building projects known from the thirteenth century BCE. For this purpose, I briefly compare these with domestic structures from the Archaic and Classical period, known to be of roughly the same building style and materials for much of the pre-industrial era in the region. Additionally, since agricultural activities were crucial to sustain the mainly agrarian population of Late Bronze Age Argive Plain and farming is very seasonally tied to the land, energy spent for such activities are taken into account as well. Finally, a hint of work done by various craft communities are looked into. None of the mentioned spheres of practice (building, agriculture, crafting) can be calculated in an exhaustive fashion for this paper, ${ }^{14}$ but, so far, it has not even been suggested in energy terms that this was people's daily reality, including that of children. All too often such tasks are studied separately creating useful but fragmented data while, in reality, people performed many embedded tasks. This is also attested in the limited but contemporary Mycenaean Linear B textual evidence that indicate the multiple jobs that many people seemed to have been involved in, quite similar as is also the case today. The energetics perspective helps to be aware of the socio-political and economic complexity present in the thirteenth century BCE, and to understand the accumulated crises (climate changes, war, resource depletion, famine, earthquakes and floods, breakdown of trade networks $)^{15}$ in view of the dynamics of interconnected and embedded economies that played their role in this period.

\section{Monumental building}

A recent reassessment of existing published data has indicated that building the six largest monuments of the late 14th to 13th century $\mathrm{BCE}$ in the Argive plain would have taken together minimally 100 people at least 17.6 years of constant building if they had been able to work all year round at a pace of 8 hours/day (Table 1). The considered monuments are the citadels of Tiryns, Mycenae and Midea, the dam at Tiryns, and the tholoi of Atreus (figure 1) and Clytemnestra. While road building, ${ }^{17}$ tomb construction, and several less costly tasks 


\section{Forces of the hands, forces of the lands}

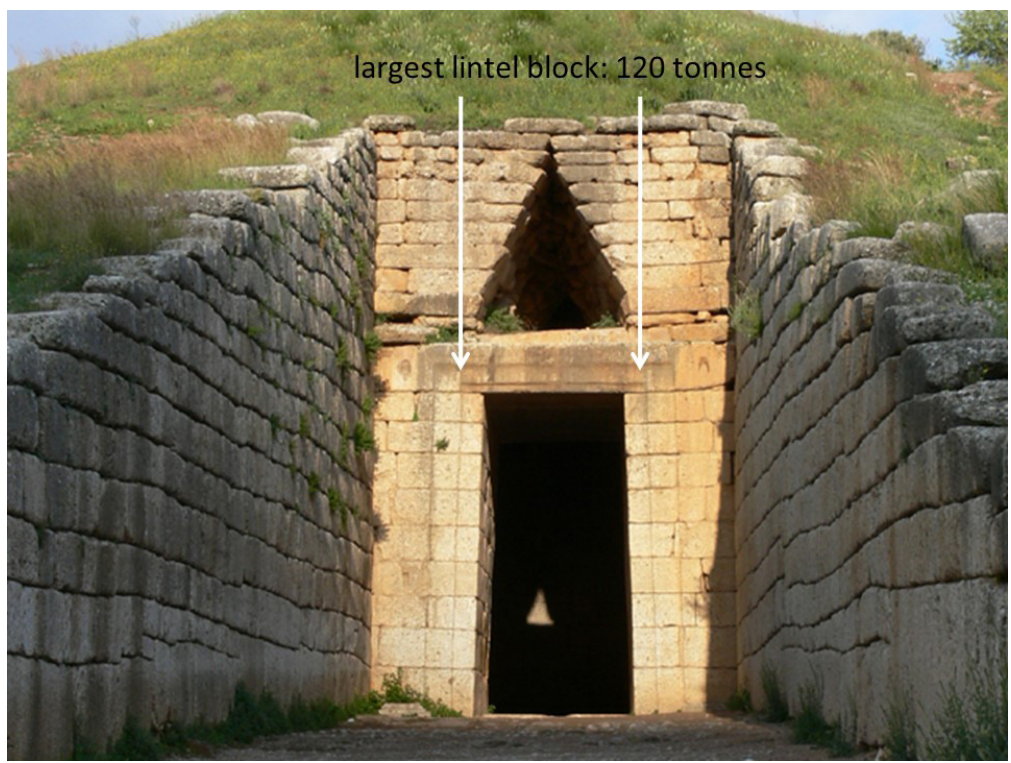

Figure 1. View of the tholos of Atreus at Mycenae: parts of the dromos and facade of the Stomion in frontal view. (Image: Ann Brysbaert)

\begin{tabular}{|l|l|l|l|}
\hline Standard $\mathbf{1 0 0}$ m wall & People + oxen & 中Tiryns $\mathbf{7 2 5}$ m wall & †Tiryns Dam \\
\hline Yr 1 & $25+10$ & $180+22$ & $50+2$ \\
\hline Yr 2 & $30+10$ & $210+22$ & $50+2$ \\
\hline Yr 3 & $33+10$ & $236+22$ & $50+2$ \\
\hline \$Mycenae 980 m wall & *Mycenae Atreus & $\begin{array}{l}\text { *Mycenae } \\
\text { Clytemnestra }\end{array}$ & \$Midea 462 m wall \\
\hline $245+22$ & $82+4$ & $82+4$ & $116+10$ \\
\hline $297+22$ & $82+4$ & $82+4$ & $139+10$ \\
\hline $324+22$ & & & $152+10 / 20 ?$ \\
\hline
\end{tabular}

Table 1. Working teams of people and oxen calculated per year for two or three full years, and relating to the volume and masses of materials needed to complete a construction as a whole. The grey cells refer to a standard set of calculations extracted from Brysbaert 2015 \& 2013 (data adapted from ${ }^{*}$ Cavanagh and Mee 1999 and updated with Harper 2016; †Loader 1998, app. 4 and updated with $\ddagger$ Brysbaert 2015, 2013). ${ }^{16}$ 


\section{Brysbaert}

increase that figure when taken into account (site clearing, foundation digging, additional openings made/closed) ${ }_{1}^{18}$ building at this scale depended on a substantial proportion of the available human and animal energy resources, especially in absolute terms. While more than 100 people could have been at work simultaneously for specific periods (Table 1 ) ${ }^{19}$ other tasks needed to be performed as well for the builders to have access to food, tools, housing, and other basic needs. Building activities were thus likely spread out over the year when agricultural pressure was low (Table 2) if the builders were also the local farmers. Nakassis discussed wall-builders, an 'all-builder', and carpenters mentioned on the Linear B tablets. This could suggest a small specialised workforce in building (perhaps even moving around from place to place), for certain tasks but these would have locally also recruited large additional crews, likely among the local population, thus the farmers. ${ }^{20}$ It is precisely in relation to this wider context that calculated absolute cost figures gain their value beyond their obvious relative importance. What is meant here is that comparing cost figures (e.g. building a house takes less energy than building a fortification wall) has its value but only absolute cost figures provide how the work done and the energy spent was spread out over the year, over the amount of people, and is set in its archaeological context for further interpretation (see discussion and conclusion section).

\section{Domestic house construction}

In a study on Greek Classical and Hellenistic private houses in Attica, Pakkanen ${ }^{23}$ writes: 'The total cost of a single storey house with a flat [clay waterproof] roof would have been approximately the same as an annual salary of a craftsman, ${ }^{24}$ so quite reasonable. The costs are based on using mudbrick, timber and clay for flat waterproof roofs. Taken into account are the excavation of the foundations and a cistern, quarrying, transporting and constructing rubble foundations, stone threshold blocks and mudbrick walls, and the use of and construction with timber. This totalled to 350 persondays (10 person-hours/day) for a plot and floor area of $240 \mathrm{~m}^{2}$, or c. 12 person-hours $/ \mathrm{m}^{2}$. Houses of $50-100 \mathrm{~m}^{2}$, the most common house size range (one third) in Mycenaean domestic architecture at the well-studied site of Kalamianos, ${ }^{25}$ would have taken 600 or 1200 person-hours respectively, or 75 or 150 person-days (Table 3) when taking into account eight hour working days $^{26}$ to stay in line with the building day rates for the six monuments. Private housing could also be substantially larger and several are known 
Forces of the hands, forces of the lands

\begin{tabular}{|c|c|c|c|c|c|c|c|}
\hline Month & $\begin{array}{l}\text { Till } \\
\text { Plough }\end{array}$ & Sow & Harvest* & $\begin{array}{l}\text { Crop process } \\
\text { Grind daily }\end{array}$ & Land management $\ddagger$ & $\begin{array}{l}\text { Animal husbandry/ } \\
\text { gathering }\end{array}$ & $\begin{array}{l}\text { Building (B) } \\
\text { Produce } \\
\text { ceramics (C) }\end{array}$ \\
\hline Jan. & \multirow[t]{2}{*}{$\begin{array}{l}\text { Plough } \\
\text { to sow }\end{array}$} & \multirow{2}{*}{$\begin{array}{l}\text { Lentils, } \\
\text { peas, } \\
\text { bitter } \\
\text { vetch }\end{array}$} & & & \multirow{2}{*}{$\begin{array}{l}\text { Weed, } \\
\text { Clear fields, } \\
\text { Extend/improve } \\
\text { Fallow/Crop } \\
\text { Rotation/mix }\end{array}$} & $\begin{array}{l}\text { Lamb and kidd } \\
\text { Milk \& process milk }\end{array}$ & \\
\hline Feb. & & & & & & & \\
\hline Mar. & & $\begin{array}{l}\text { Pulses, } \\
\text { beans }\end{array}$ & & & Weed & \multirow{2}{*}{$\begin{array}{l}\text { Sheer sheep } \\
\text { Calve, milk \& process } \\
\text { milk } \\
\text { Sheep to mountains }\end{array}$} & \\
\hline April & & & & & \multirow[t]{2}{*}{ Cross-plough } & & C \\
\hline May & & & $\begin{array}{l}\text { Pulses, } \\
\text { grain }\end{array}$ & & & $\begin{array}{l}\text { Gather leaves, } \\
\text { shoots, fruits, seeds, } \\
\text { nuts }^{i}\end{array}$ & $\mathrm{C}-\mathrm{B} ?$ \\
\hline June & & & \multirow{2}{*}{$\begin{array}{l}\text { Grain, } \\
\text { then } \\
\text { pulses }\end{array}$} & \multirow{2}{*}{$\begin{array}{l}\text { Thresh grain, } \\
\text { then pulses }\end{array}$} & \multirow{3}{*}{$\begin{array}{l}\text { Weed during harvest } \\
\text { Manure after harvest } \\
\text { Plough fallow fields }\end{array}$} & & $\mathrm{C}$ \\
\hline July & & & & & & $\begin{array}{l}\text { Gather leaves, } \\
\text { shoots, fruits, seeds, } \\
\text { nuts }\end{array}$ & c \\
\hline Aug. & & & $\begin{array}{l}\text { Pulses/ } \\
\text { beans }\end{array}$ & & & $\begin{array}{l}\text { Cull old sheep, goat, } \\
\text { cattle }\end{array}$ & $\mathrm{C}-\mathrm{B}$ \\
\hline Sept. & & \multirow{4}{*}{$\begin{array}{l}\text { Wheat, } \\
\text { barley, } \\
\text { oat, rye }\end{array}$} & & & \multirow{4}{*}{$\begin{array}{l}\text { Manure before sow, } \\
\text { clear field } \\
\text { Fell timber \& season } \\
\text { wood }\end{array}$} & $\begin{array}{l}\text { Spin, weave, hunt, } \\
\text { fish }\end{array}$ & $\mathrm{C}-\mathrm{B}$ \\
\hline Oct. & \multirow{3}{*}{$\begin{array}{l}\text { Plough } \\
\text { to sow }\end{array}$} & & & & & \multirow{3}{*}{$\begin{array}{l}\text { Milk new lambs } \\
\text { Lamb and kidd }\end{array}$} & B \\
\hline Nov. & & & & & & & B \\
\hline Dec & & & & & & & \\
\hline
\end{tabular}

Table 2. Life cycle calendar indicating which activities took place per month. Bold italic indicates most crucial task/period. ${ }^{\star}$ Harvest includes reaping, binding, drying, and transporting. †Crop processing includes threshing, winnowing, transporting sheaves, sieving, grinding, and storing. $\ddagger$ Land management includes fallowing/crop rotating, mixed cropping, manuring, weeding and extending/improving (based on Hesiod Works and Days, 420; Forbes 1989; Halstead 2014; Fitzjohn 2013; Blitzer 1990; Koster 1977; Dahl and Hjort 1976). ${ }^{22}$

from Mycenae. A study on Archaic houses in southeast Sicily refers to similar house types and materials (stone, mudbrick, wood) as prehistoric houses and later Classical ones. ${ }^{27}$ An 8th c. BCE one room house of 12.25 $\mathrm{m}^{2}$ from Syracuse would have taken 24 person-days +30 oxen-days, thus taking at a converted rate of eight hours/day about 1.5 to 2 person-days $/ \mathrm{m}^{2}$. This is slightly higher than Pakkanen's rate but still similar when compared to monumental construction requirements.

Table 3 shows a rough split of the Argive Plain's estimated population into 4000 five-members-households, ${ }^{28}$ and how larger $\left(100 \mathrm{~m}^{2}\right)$ versus smaller houses $\left(50 \mathrm{~m}^{2}\right)$ may have been distributed in a ratio 1:3, and against their building costs expressed in person-days. Building a private house will have been achieved easily enough by two-four people ${ }^{29}$ who were likely family members and who spread this job among the moments free of agricultural labour (Table 2). Building is calculated for 365 days/year. Again, if 100 people were building all year around on the domestic housing needed within 


\begin{tabular}{|l|l|l|}
\hline \multicolumn{2}{|c|}{$\begin{array}{c}\text { Estimated Argive Plain population: } \\
\text { or } \mathbf{4 , 0 0 0} \text { households of five memble (13 }\end{array}$} \\
\hline & Large houses & BCE) \\
& 31 \\
\hline Amount & 1000 & Small houses \\
\hline Cost/unit & $150 \mathrm{pd}$ & 3000 \\
\hline Cost for all & $150,000 \mathrm{pd}$ & $75 \mathrm{pd}$ \\
\hline Cost for all over 13th c. BCE ${ }^{32}$ & $300,000 \mathrm{pd}$ & $225,000 \mathrm{pd}$ \\
\hline $\mathbf{4}$ builders/unit & 75 & $450,000 \mathrm{pd}$ \\
\hline $\mathbf{4}$ builders for all/size & $\mathbf{7 5 , 0 0 0}$ days (= 205 years) & $\mathbf{1 1 2 , 5 0 0}$ days (= $\mathbf{3 0 8}$ years) \\
\hline $\mathbf{1 0 0}$ builders for all houses & $\mathbf{7 , 5 0 0}$ days (= 20.6 years) \\
\hline
\end{tabular}

Table 3. Cost of domestic house building for the Argive Plain households for an entire century. that century, they would be building for 20.6 years. The same agricultural calendar, however, would be dictating this work as well and make people spread out the construction work possibly over a full year period..$^{30}$

\section{Agricultural production}

Table 4 shows the energy expenditure or labour cost rates and totals of the detailed chaîne opératoire of a mixed crop production needed to sustain a household. A slightly higher rate for a household is given here (from 800 to $1000 \mathrm{~kg}$ of grain/household $)^{33}$ to take the cultivation of pulses into account. A balanced combination of both pulses and cereals sown on 1.5 ha for each would be done so strategically to maintain soil fertility, ${ }^{34}$ to lengthen harvest periods (from c. one to two months, see Table 2), and to spread the risk of crop failure of one or the other. ${ }^{35}$ When done small-scale, the more energyconsuming pulse cultivation did not affect labour requirements badly. Pulse cultivation was more intensive in harvesting, but faster in threshing and when done in garden plots, regular watering was needed. Table 4 clearly shows that producing 3 ha worth of crops needed minimally two adults, while 5 ha required at least four adults and other less strong hands, when working eight hours each day of the year (although most farmers work 10 hours/day on average).

Separate calculations of the energy spent in rearing animals is not included here because such figures would depend on which animals and how many people reared which is difficult to estimate. ${ }^{40}$ The individual cost of an animal can be determined and from time to time new animals would have to be bought to keep the existing pool healthy and to replace the slaughtered and dead ones. About 20 months-worth of wheat (half to $65-70 \%$ of his/her total food calories intake) or $150-200 \mathrm{~kg} /$ year is the cost of one adult slave 
Forces of the hands, forces of the lands

\begin{tabular}{|c|c|c|c|c|}
\hline \multirow[t]{2}{*}{ Task } & \multirow[t]{2}{*}{ Labour cost rate } & \multicolumn{3}{|c|}{ Labour in person-days (pd) } \\
\hline & & 1 ha & 3 ha $^{36}$ & 5 ha \\
\hline Tilling-sowing & $0.01-0.03 \mathrm{ha} / \mathrm{pd}$ & $34-100$ & $102-300$ & $170-500$ \\
\hline Reaping & $0.1 \mathrm{ha} / \mathrm{pd}^{37}$ & $10-13$ & $30-39$ & $50-65$ \\
\hline Manual threshing & $100-300 \mathrm{~kg} / \mathrm{pd}$ & $3.75-10$ & $11.25-30$ & $18.75-50$ \\
\hline Dehusking & $100-300 \mathrm{~kg} / \mathrm{pd}$ & $3.75-10$ & $11.25-30$ & $18.75-50$ \\
\hline Crop cleaning & Variable/person & 25 & 75 & 125 \\
\hline $\begin{array}{ll}\text { Total without } \\
\text { grinding }\end{array}$ & & $76.25-\underline{157.5}$ & $228.75-\underline{472.5}$ & $381.25-\underline{787.5}$ \\
\hline Grinding into flour ${ }^{38}$ & $3 \mathrm{hrs} /$ day (2 kg?) & $\underline{162.6}$ & $\underline{487.8}$ & $\underline{813}$ \\
\hline $\begin{array}{l}\text { Adult requirements } \\
\text { for } 365 \text { days/yr }\end{array}$ & & 0.9 & 2.6 & 4.4 \\
\hline
\end{tabular}

Table 4. Agricultural tasks for crop rearing including rates for production and preparation for consumption, labour cost rates, and labour efforts/task, with totals. Adapted from Halstead (2014, table 4.1). 3 ha of cultivated land as the minimal need of a 5 member household, ${ }^{39} 5$ ha as plot size to start using draft animals.

in Classical times ${ }^{41}$ and Table 5 relates these figures to the cost of several animals. When relating these figures to the $800 \mathrm{~kg} /$ person/year on emmer consumption ${ }^{42}$ and 2 adults would consume c. $180 \mathrm{~kg} /$ person and the elder/ children c. $147 \mathrm{~kg} /$ person, the animal cost figures can be put in perspective: e.g. the cost of buying 10 goats equals feeding one child or elder for the year with cereals at the lowest rate of $150 \mathrm{~kg} /$ year. Finally, also Table 2, the calendar, shows that rearing animals is prominently present throughout the year and that especially lambing, calving, milking the young animals, and processing the milk is time-consuming and time-sensitive. Herding animals in the mountains will also take people away from the farm although children have been known to do such work, at least for the day. 


\begin{tabular}{|l|l|l|l|}
\hline Animal & Amount & $\begin{array}{l}\text { Adult food need/month } \\
\text { X 20 months (for } \mathrm{nbr} \text { of animal } \\
\text { type) }\end{array}$ & $\begin{array}{l}\text { Individual cost/animal in } \mathrm{kg} \text { of } \\
\text { wheat }\end{array}$ \\
\hline Cattle & 2 & $12.5-16.6 \times 20(2)$ & $125-166.6 \mathrm{~kg}$ \\
\hline Sheep & $16-20$ & $12.5-16.6 \times 20(16-20)$ & $15.6-20.75 \mathrm{~kg}$ (for 16) \\
& 16 & $12.5-16.6 \times 20(16)$ & $15.6-20.75$ (for 16) \\
\hline Goat & 16 & & \\
\hline
\end{tabular}

Table 5. Animal cost related to the cost of a slave in Classical times; pig figures were not available (based on Gallant 1991: table 4.2) ${ }^{44}$

\section{Material culture production: the case of pottery-making}

A picture of energy-spending cannot be complete without inquiring into people's need for metal and non-metal tools and weapons, pottery for daily and other practices, wood for fuel, clothing, cosmetic, aromatic and other decorative production lines such as those based on military, social, and religious activities and practices. ${ }^{45}$ The Linear $\mathrm{B}$ tablets with their constraints in time and space illustrate the diversification of the tasks carried out in the LBA Aegean by multiple people sometimes active in multiple jobs. ${ }^{46}$ Nakassis recognized a significant overlap between the personal names of metal smiths and the names of herders which can only be interpreted as several of them having multiple job responsibilities towards the palaces. ${ }^{47} \mathrm{He}$ also asserts that some individuals also may have had a patchwork of tasks beyond the palatial economic sphere too. ${ }^{48}$ This illustrates a high level of mobility of many artisans and crafters and this also has implications for their remuneration: a travelling potter or metal worker may not feel that payment in barley is very useful when moving frequently. More to the point is trying to measure potters' energy expenditure in making the pots ${ }^{49}$ either by travelling artisans, those in fixed workshops, or done within the household. In order to get the overall picture, it is necessary to generalize the principal factors. I assume one kiln of $1 \mathrm{~m} 2$ diameter $\mathrm{x} 1 \mathrm{~m}$ in height, ${ }^{50}$ and this determines the amount of work needed to fill it up for one firing of undecorated, wheel-turned small, medium and large-sized ${ }^{51}$ vessels which optimized kiln capacity in line with 
calculating minimum costs. The entire operation, from clay preparation to throwing, shaping, loading, firing and removing from kiln, from the cold kiln, over firing, and back to cooling for removal of item, took a full day with a team of five ${ }^{52}$ and would have produced a range of vessels totaling to possibly 50 mixed items/kiln load. ${ }^{53}$ This assumes that the kiln, all raw materials, fuel, water, and tools are all present. Potting likely was not a timecritical or a full-time activity, and each worker could do other tasks in and beyond the workshop. Crucial to know, though, is how many vessels are consumed per household of average means. Pottery production likely took place in the summer months to allow for drying the clay before firing. ${ }^{54}$ Next to the incomplete number of 37 vessels in the small House III of the Panagia Houses (Mycenae), Whitelaw ${ }^{55}$ estimates 50-100 vessels per lower income household of which some pithoi remaining in long-term use. For the Argive Plain with its estimated 4,000 households (see above), between 200,000 or 400,000 pots would have been consumed annually in the region. Table 6 brings all data together and shows that if pottery making was indeed executed full-time in workshops but limited by the 6 drier months of the year, a doubling of the final numbers, especially if a household had up to 100 vessels, would be needed. If people thus had closer to 100 pots/household, 44 full-time workshops would be needed and 182 days/year (six months).

\begin{tabular}{|l|l|l|}
\hline \multicolumn{3}{|c|}{ Estimated pottery needs for $\mathbf{4 , 0 0 0}$ households in the Argive Plain per year } \\
\hline & 50 per household & 100 per household \\
\hline Amount & 200,000 & 400,000 \\
\hline Cost/unit & 6.7 pots $/ \mathrm{ph}^{*}=54 / \mathrm{pd}$ & $6.7 \mathrm{pots} / \mathrm{ph}^{*}=54 / \mathrm{pd}$ \\
\hline Cost for all & $3979 \mathrm{pd}$ & $7940 \mathrm{pd}$ \\
\hline Cost per year & $11 \mathrm{py}$ or 11 potters & $22 \mathrm{py}$ or 22 potters \\
\hline Team of 5/workshop & $\mathbf{5 5}$ py or potters with team & $\mathbf{1 1 0}$ py or potters with team \\
\hline
\end{tabular}

Table 6. Yearly cost of pottery needs for the estimated households of the Argive Plain. Based on Whitelaw (2001) and Acton (2014). ${ }^{56}{ }^{*}$ Refers only to the potter (see Whitelaw 2001). Acton suggests 5 people/workshop. ${ }^{57}$ 


\section{Brysbaert}

\section{Discussion and Conclusion}

(1) Physically active and pro-active strategies of energy-expenditure

Based on the above preliminary labour calculations, if the work was divided equally throughout the 13th century BCE, in a typical year, a minimum of 9000 adults would have been needed full-time, at least for two thirds of the year in agriculture, approximately 40 persons would have been needed fulltime in construction, including for the construction of both monumental buildings and houses (at 365 days/year), and 55 to 110 persons in pottery making (at 365 days/year). Additional workforce would have been needed for weaving, collecting firewood, smithing, tomb building, tool making, and any other craft activity. As we see, even based on this summary, the importance of all other activities is overshadowed by the labour requirements of agriculture, which, however, need to produce enough surplus to provide for carrying out the other tasks. Under stable conditions, an adult workforce of c. 6,000-10,000 $0^{58}$, of which half are male and the other half female, would have just managed the agricultural work and some of these would work in different jobs for part of the year. Having taken here the available adults of the Argive Plain together suggests a model of one central authority (Mycenae), who created and maintained alliances with less powerful citadels (Tiryns and Midea) and who centralized available resources (here labour force), although creating and maintaining alliances signifies both power and fragility in the bonds created. ${ }^{59}$ This stands in contrast to a situation in which each citadel would be more independent, and thus have access to a more limited pool of people to carry out these series of large-scale building works. It should be clear from the above that people had to work together on these monuments to make them happen while also looking after each other for food, housing, clothing and many other material needs. Pooling people and efforts from among all citadels thus seem to be the only way that this can be achieved and this needs a central organisation in charge.

Based on Abrams and Bolland's spreadsheet model, ${ }^{60}$ the life cycle calendar (Table 2), however, clearly marks out that there was very little idle time and that the crucial agricultural tasks of tilling/ploughing and sowing, harvesting, and processing/storing of crops ideally took precedence over all others. This is unsurprising if agriculture is people's main means of subsistence and if they had to balance their energy expenditures carefully, based on seasonal requirements for all to survive, especially when faced with bad harvests (see 
below). All other labour-intensive activities should be, ideally, fitted around the seasonally-bound agricultural cycle, to avoid neglect or lack of available hands. Workers themselves likely kept a mental calendar to know when to call on additional hands, and it will have aided in planning and organizing large-scale and long-term jobs. ${ }^{61}$ Understanding energy expenditure from this perspective suggests large levels of responsibility and pro-activeness in the hands of the farmers and workers rather than allowing the elites to rule the scene at all times (further discussed below). The Argive Plain societies had already shown remarkable resilience in rapidly changing conditions and their adaptive skills were remarkable. Tiryns Lower Town did not suffer catastrophic flash floods, as once believed, ${ }^{62}$ but regular ones over long periods of time, leading to the construction of a dam around c. $1220 \mathrm{BCE}$ to solve their problem. ${ }^{6}$ Mycenae, Tiryns and Midea citadels experienced devastating earthquakes c. $1300 \mathrm{BCE}$, but both Mycenae and Tiryns actually expanded (in LH IIIB2) in terms of buildings and craft activities; ${ }^{64}$ fires were regular events, but these did not result in people changing their usual activities ${ }^{65}$ It is therefore unlikely that earthquakes alone would have brought an end to these strongholds c. $1200 \mathrm{BCE}^{66}$ and certainly not to entire Mycenaean polities.

Both Manning and $\mathrm{McHugh}^{67}$ see the peasants and their farmsteads at the bottom of the food chain as the crucial group of influence, a conclusion also reached in this paper. Harvests were regularly prone to a single bad year in a period of 100 years. However, two crop failures after each other would be disastrous while this was a rare phenomenon. ${ }^{68}$ It is also clear from both archaeological and ethnographic accounts that food storage strategies could handle 1-2 years of surplus to cover for bad harvests. ${ }^{69}$ In times of trouble, the problems would move up the chain when several bad harvests, ranging from mild food shortage to famine, could cause unrest. ${ }^{70}$ Within this group, households make crucial decisions: crop selections, labour scheduling, and disposal of final produce. ${ }^{71}$ By taking birth, death and marriage factors into account, a household becomes a totally dynamic and social affair and these constant changes strongly affect both the family's economic and their labour potential over time. Moreover, "simply stating that the average farm was on the order of 4 to 6 hectares does not go far enough because it omits the fact that land-holdings, like the household itself, do not remain static over time". ${ }^{72}$ The Linear B evidence suggests diversity in land tenure as well, ${ }^{73}$ so plot sizes may have varied over time and may have been established and adapted from pre-palatial systems. ${ }^{74}$ This seems to support Gallant's changing household structure: ${ }^{75}$ land fragmentation upon inheritance and dowry divisions 


\section{Brysbaert}

seems a logical and useful strategy against the effects of bad harvests. Also Osborne recognized this pro-active strategy in Classical times. ${ }^{76}$ While land fragmentation may been caused initially by inheritance or selling off, it did distribute risks better than when all was based in the same region when it would be affected by unfavourable circumstances. Investigating how people faired towards $1200 \mathrm{BCE}$ would need to be researched at a household level; data to study the Mycenaean past is naturally lacking, but ethnographic data is revealing when used cautiously.

Greek pre-industrial farmers tried to overproduce on average for a second year in case one year's worth of grain would not suffice. ${ }^{77}$ People thus employed practical strategies to protect themselves against a single bad harvest. Storing dehusked grain would cause issues with vermin and moulds so it was ground into flour. Storing grain two or three years underground was possible when covered well, but the length of storage increased risks with high humidity. ${ }^{78}$ The frequency with which people would have suffered due to crop failure would have depended (1) on their capacity to store enough for long enough, (2) on their ability to distribute foodstuffs where needed, and (3) on their willingness to eat the crops that grew best in their region. ${ }^{79}$ Studying storage capacities that would have allowed for at least one to two extra years of supplies entails the knowledge of how many people lived in a specific place where storage containers were preserved. Until recently, grain and other dry food stuffs have been stored in woven sacks, baskets, wooden chests, heaped on the ground, or sank in pits dug in soft marl under houses. ${ }^{80}$ The pits aside, such organic containers would not easily be recognized in LBA houses thus skewing the picture of what could have been stored in any given household or palatial store. Greek farmers who stored for two years would have needed about 2-3 tons of naked grain while Cretan households held about 2200 litres of storage for all their food stuffs to foresee them in subsistence for one, maximum two, years. ${ }^{81}$

When a household needed extra hands, neighbouring people pooled efforts in alteration at crucial peak times. The fit adult males and females would conduct the most strenuous tasks such as hand tilling, reaping, threshing and winnowing. The elderly and children would sieve after threshing. Adolescents and many women would follow the plough to pick weeds and break up soil clods, and helped in heavier tasks as apprentices. When, during harvest, every hand was needed, one in three women may have cooked for several households, freeing the others up for the fields. The heavier tasks would have been made easier by the use of animals provided 
there was sufficient land (see below). Such collaborative practices are again practical coping mechanisms for periods with serious time constraints such as harvesting times. ${ }^{82}$

Subsistence disruptions can also be caused by human activity with or without the aid of nature. This is important for us in considering the LBA relations between those that were building long-term and large-scale, and those that were farming. According to Garnsey ${ }^{83}$ frequency and severity of subsistence crises will vary with the incidence of imperialism, war, piracy, civil strife and the economic and non-economic heavy exploitation of labour, producers and consumers by the powerful, ${ }^{84}$ respecting that the seasonal cycle is crucial to both building and agricultural activities in avoiding crop failure by employing the human workforce at the wrong times for the wrong jobs.

(2) Social strategies of energy-expenditure

Energy-spending is not just a physical process but also socially and symbolically-laden one. It is not only the amount of energy spent in labour that has social connotations, but equally the way it is spent, and this becomes the measure for inequality as amply indicated in discussing the ownership of draft animals. ${ }^{85}$ A poor farmer who had to supplement the household income by working on someone else's land had lower social status than those spending the same amount of time and energy on harvesting with oxen that they could afford. ${ }^{86}$ Halstead sees a similar inequality in the hierarchical value attached to barley (for the poor) ${ }^{87}$ and the same is applicable to social storage strategies in which food surplus is converted through formalized exchange networks into durable tokens and social obligations that can be reconverted into food in times of shortage. ${ }^{88}$ Intra-corporeal storage, finally, ensures that body fat can remain at a healthy level, and well-fed animals can be converted to meals in lean times, ${ }^{89}$ again favouring those who owned animals. For their grain harvest, Linear B evidence from Pylos suggests that its Mycenaean palace depended on their collaboration with the dāmos in many interesting ways: the palaces provided oxen for grain tillage and harvest collection while the dāmos provided the manual labour as they owned substantial lands themselves. ${ }^{90}$ As such, there was a clear understanding of harvest division. Similar arguments were made for the citadel building processes in Tiryns ${ }^{91}$ that supports the conclusions reached here: building and agriculture were strongly bound up within the palace- dāmos relations in which the palace depended on the dāmos for their labour needs. Moreover, if the palaces were 


\section{Brysbaert}

strategic in their conduct of their day-to-day business in working closely together with the dāmos for their labour in harvesting, it seems logical that they would do the same for the labour needed for building. There is, however, no evidence in any direction whether the palace administration was strategic about it. Would it, therefore, be far-fetched that unequal labour access and potential unequal harvest divisions (through growing taxation?) ${ }^{92}$ may have formed a bone of contention between the parties? Perhaps the dāmos as a whole was, at some point, no longer interested in providing the labour to the ever demanding palatial elites and resorted to halting both the large-scale building and land-working with palace oxen for a more small-scale land cultivation by hand and their own cattle, and to diversifying their crops more. Hypothetically, the pre-existing dāmos could have come out of this struggle as the stronger party and may have even led revolts against the central authority if needed. After the dissolution of the palace administration, people could have returned to their agricultural and artisanal tasks once more but without additional strain on their energetic capacities.

Our expanding knowledge about the periods after the LBA crises shows that the settlement areas linked to the former palaces were not immediately reduced in size or ceased to exist. ${ }^{93}$ Midea showed signs of cultural continuity in the LH IIIB and IIIC ceramics found near the megaron, on the lower terraces where walls were reused or repaired, and people just returned. ${ }^{94}$ Certain activities at these centres indicate continuity: religious activities, repairs within the fortifications and building within the citadels and beyond, building on top and in the megara themselves, while others did decline drastically, both settlements and cemeteries, ${ }^{95}$ so people likely moved away. In order to survive, people need both energy and knowledge about how to consume and preserve these. Creative adaptations to restraining factors must have affected several socioeconomic and political groups differently even in single contexts. ${ }^{96}$ Demise and crisis can be devastating for some people but may have simultaneously created opportunities for others. For example, the dāmos may have reclaimed its former pre-palatial status and perhaps this was combined with the status of the older religious sector too, ${ }^{97}$ or political alliances with neighbouring citadels were falling apart and these were then reclaiming their own labour resources.

Growing social complexity as a strategy to achieve potential for continuous successful problem-solving can thus require high costs in energy, resources and time.${ }^{98}$ The logistics and carrying out of monumental building and largescale agricultural undertakings for the palaces form good examples. While 
social complexity is fundamentally linked to sustainability, it can enhance but also undermine it when demands on energy-input are too high, because this relationship is not constant or direct. In times of crises when societal survival is at stake, costly problem-solving tactics may no longer be wanted or possible. In such times, expensive tactics for sustainability may temporarily be abandoned and replaced by people's creative actions and resiliency to adverse conditions such as resource depletion. Less complex ways of life (abandoning monumental construction) may offer a less costly survival strategy for most people, irrespective of whether the socioeconomic and political structures, of which they are part, survive or not. ${ }^{99}$

The architectural and material production tasks carried out in the region (Tables 1,3-6) eventually had to take back stage to agricultural work, since it would have been economic suicide to act otherwise. Whether it did, however, is unclear. Final figures are not yet available but multitasking on the scale briefly and incompletely presented here for the Argive Plain must have had some impact on day-to-day life for perhaps a part of the population, the poorer ones, whether living in the lower towns of the respective citadels, or further afield in the fertile plateau of Berbati, Limnes, Stefani, Kephalari, and Nemea. The impact of the building programmes within all these tasks is far from obvious at this stage but any further attempt to build a general narrative for a 'monolithic Mycenaean society' and its collapse can no longer be tenable.

\section{Acknowledgements}

I thank Dr. B. Lis for sharing his expertise knowledge on Mycenaean undecorated pottery and providing me with useful references, and prof. J. Pakkanen for proofreading and commenting on a draft of this paper. Thanks go to Ms. I. Vikatou who was very helpful in providing references and checking the endnotes/citations thoroughly. This research is part of the ERC-Consolidator SETinSTONE project under the direction of Prof. A. Brysbaert, Leiden University, and funded by the European Research Council under the European Union's Horizon 2020 Programme / ERC grant agreement $n^{\circ} 646667$. 


\section{Brysbaert}

\section{Notes}

1. See Guy D. Middleton, "Nothing Lasts Forever: Environmental Discourses on the Collapse of Past Societies," Journal of Archaeological Research 20, no. 3 (January 2012): 257-307, https://doi.org/10.1007/s10814-011-9054-1.

2. See Richard Hope Simpson, and Dietmar K. Hagel, Mycenaean Fortifications, Highways, Dams and Canals (Sävedalen: Åström Editions, 2006) for an overview.

3. E.g. Galaty, Michael.L. and William A. Parkinson (eds) Rethinking Mycenaean Palaces II. (Los Angeles: Cotsen Institute of Archaeology, University of California, 2007.)

4. Diamond, Jared. Collapse. How Societies Choose to Fail or Survive. New York: Viking Press, 2005; Guy D. Middleton, "Nothing Lasts Forever: Environmental Discourses on the Collapse of Past Societies," Journal of Archaeological Research 20, no. 3 (January 2012): 257-307, https://doi.org/10.1007/s10814-011-9054-1.

5. E.g. Joseph Maran, "Tiryns," in The Oxford Handbook of the Aegean Bronze Age, ed. Eric H. Cline (Oxford: Oxford University Press, 2010), 722; Richard Hope Simpson, and Dietmar K. Hagel, Mycenaean Fortifications, Highways, Dams and Canals (Sävedalen: Åström Editions, 2006).

6. An average life-span of any adult has been estimated to 38 (female) and 40 (male) years. Child mortality rate was $50-60 \%$ and 2.7 per family children survived this, see Thomas W. Gallant, Risk and survival in Ancient Greece. Reconstructing the Ancient Economy (Cambridge: Polity Press, 1991), 18-20.

7. Ann Brysbaert, "Set in Stone? Socio-economic reflections on human and animal resources in monumental architecture of Late Bronze Age Tiryns in the Argos Plain, Greece", Arctos 47 (January 2013), 50; Ann Brysbaert, "Set in stone? Constructed symbolism viewed through an architectural energetics' lens at Bronze Age Tiryns, Greece," in Excerpta Archaeologica Leidensia. Analecta Praehistorica Leidensia 45, ed. Corrie Bakels, and Hans Kamermans (Leuven: Peeters, 2015), 91.

8. Minoan architecture: Maud Devolder, Construire en Crète Minoenne. Une Approche Energétique de l'Architecture Néopalatiale. Aegaeum 35 (Leuven/Liège: Peeters, 2013); Mycenaean tombs: Rodney D. Fitzsimons, "Monumental architecture and the construction of the Mycenaean state," in State Formation in Italy and Greece: Questioning the Neoevolutionist Paradigm, ed. Nicola Terrenato, and Donald C. Haggis (Oxford: Oxbow, 2011); Mycenaean fortifications: Brysbaert, "Socio-economic reflections"; Brysbaert, "Constructed symbolism."

9. AIAC Bonn conference 2018 sessions; Alison Burford, "Heavy Transport in Classical Antiquity." The Economic History Review, New Series 13, no. 1 (1960), DOI:10.2307/2591403; Janete DeLaine, The Baths of Caracalla: a Study in the Design, Construction, and Economics of large-scale Building Projects in Imperial Rome. (Portsmouth: Journal of Roman Archaeology, 1997); H. Jan De Haan, "Building the great pyramid by levering. A mathematical model”, PalArch's Journal of Egyptology6, no. 2 (May 2009); Jari Pakkanen, Classical Greek Architectural Design: a Quantitative Approach. Papers and Monographs of the Finnish Institute at Athens 18 (Helsinki: Finnish Institute at Athens, 2013); Research in the Mycenaean mainland is ongoing by Yannick Boswinkel, "Labouring with Large Stones. Assessing the Impact of 


\section{Forces of the hands, forces of the lands}

Monumental Construction on Mycenaean Communities through Labour Cost Studies of Cyclopean Architecture on Mainland Greece", (PhD diss., Leiden University, Leiden, in progress) and Daniel Turner, "Comparative Earthmoving from the Late Bronze Age Aegean", (PhD diss., Leiden University, Leiden, in progress) within SETinSTONE.

10. Ann Brysbaert, "Cross-craft and cross-cultural interactions during the Aegean and Eastern Mediterranean Late Bronze Age," in Mediterranean Crossroads, ed. Sophia Antoniadou, and Anthony Pace (Athens: Pierides Foundation Publications, 2007), 325-59; Ann Brysbaert, "Introduction. Tracing social networks through studying technologies," in Tracing Prehistoric Social Networks through Technology: A Diachronic Perspective on the Aegean, ed. Ann Brysbaert (London: Routledge, 2011), 1.

11. Tim Ingold, “The temporality of the landscape." World Archaeology25, no. 2 (October 1993): 158, https://www.jstor.org/stable/124811.

12. Ann Brysbaert, "Artisans versus nobility? Crafting in context: introduction," in Artisans versus Nobility? Multiple Identities of Elites and 'Commoners' Viewed Through the Lens of Crafting from the Chalcolithic to the Iron Ages in Europe and the Mediterranean, ed. Ann Brysbaert, and Alexis Gorgues (Leiden: Sidestone Press, 2017), 15.

13. Elliot M. Abrams, How the Maya Built their World. Energetics and Ancient Architecture (Austin: University of Texas Press, 1994), 42, table 2.

14. But see Ann Brysbaert, Forces of the Hands, Forces of the Lands. A Retrospective Impact Assessment of Human and Environmental Resource Usage in Late Bronze Age Mycenaean Monumental Architecture, Greece, (Leiden: Sidestone Press, in progress).

15. For example John Bennet, "Bronze Age Greece" In P.F. Bang and W. Scheidel (eds) The Oxford Handbook of the State in the Ancient Near East and Mediterranean (Oxford: Oxford University Press, 2013), 235-58.

16. William G. Cavanagh, and Christopher B. Mee, "Building the Treasury of Atreus", in Meletemata: Studies in Aegean Archaeology Presented to Malcolm H. Wiener, ed. Philip P. Betancourt, Vassos Karageorghis, Robert Laffineur, and Wolf-Dietrich Niemeier (Liège and Austin, 1999), 95-99; Charles R. Harper, "Labouring with the economics of Mycenaean architecture. Theories, methods, and explorations of Mycenaean architectural production," (Unpublished $\mathrm{PhD}$ diss, Florida State University, Tallahassee, Florida, 2016), 243; N. Claire Loader, Building in Cyclopean Masonry with Special Reference to Mycenaean Fortifications on Mainland Greece, (Jonsered: P. Åström Förlag, 1998), app. 4; Brysbaert, "Socio-economic reflections,"101; Brysbaert, "Constructed symbolism," 81.

17. Ann Brysbaert, "From Mycenae to Tiryns on foot. Least cost path analysis of prehistoric transport costing estimates in the Late Bronze Age Argolid, Greece," in The Archaeology of Cyprus and the Mediterranean. Celebratory Conference in Honour of Professor A. B. Knapp, Cyprus University, 5-7 June 2019, ed. Sturt W. Manning, and John F. Cherry, (London: Equinox, under review).

18. Brysbaert, "Retrospective Impact Assessment".

19. Also Riia Timonen, and Ann Brysbaert, "Saving up for a rainy day? Climate events, human-induced processes, and their potential effects on people's coping strategies 


\section{Brysbaert}

in the Late Bronze Age Mycenaean Argive Plain, Greece", in Climate and Society in Ancient Worlds Diversity in Collapse and Resilience, ed. Paul Erdkamp, Joseph G. Manning, and Koenraad Verboven (Palgrave, under review).

20 . Dimitris Nakassis, "Labour Mobilization in Mycenaean Pylos", in Etudes Mycéniennes 2010. Actes du XIIIe Colloque international sur les texts égéens (Biblioteca di Pasiphae 10), ed. P. Carlier, C. de Lamberterie, M. Egetmeyer, N. Guilleux, F. Rougemont and J. Zurbach, (Pisa : F. Serra, 2012), 269-83.

21. Emphasizing the importance of this category: Gallant, Risk and survival, 68 with refs: $65-70 \%$ cereals $\times 20-25 \%$ fruits, pulses, vegetables, $5-15 \%$ oils, meat and wine, for the Classical period. But see Halstead, Two oxen ahead, 119 on pulses-cereals ratios for earlier periods.

22. Hesiod Works and Days, 420; Hamish Forbes, "Of grandfathers and grand theories: the hierarchized ordering of responses to hazard in a Greek rural community," in Bad Year Economics: Cultural Responses to Risk and Uncertainty, ed. Paul Halstead, and John O'Shea (Cambridge: Cambridge University Press., 1989); Halstead, Two oxen ahead, 182; Matthew Fitzjohn, "Brick and mortar, grain and water: tracing tasks and temporality in Archaic Sicily," World Archaeology 45, no. 4 (2013): 628-29, https://doi. org/10.1080/00438243.2013.849489; Harriet Blitzer, "Pastoral Life in the Mountains of Crete. An Ethnoarchaeological Perspective," Expedition 32, no. 3 (1990): 34-41, https://www.penn.museum/sites/expedition/pastoral-life-in-the-mountains-of-crete/; Harold A. Koster, "The Ecology of Pastoralism in Relation to Changing Patterns of Land Use in the Northeast Peloponnese" (PhD diss., University of Pennsylvania, Philadelphia, 1977); Gudrun Dahl, and Anders Hjort, Having Herds. Pastoral Herd Growth and Household Economy (Stockholm: Liber Tryck, 1976).

23. Jari Pakkanen, "Building Big and Greek Classical and Hellenistic Houses? Estimating Total Costs of Private Housing in Attica", in Building BIG - Constructing Economies: from Design to Long-Term Impact of Large-Scale Building Projects, ed. Jari Pakkanen, and Ann Brysbaert (Heidelberg: Propylaeum/Heidelberg Publishing, in press).

24. William T. Loomis, Wages, Welfare, Costs and Inflation in Classical Athens (Ann Arbor: The University of Michigan Press, 1998), 104-120, for day wages: 1 dr/day in the 5th c. BCE and 2 in the 4th; see also Pakkanen, "Private Housing in Attica".

25. Thomas F. Tartaron et al., "The Saronic Harbors Archaeological Research Project (SHARP) Investigations at Mycenaean Kalamianos, 2007-2009," Hesperia 80, no. 4 (2011): 589.

26. I have argued elsewhere why a 10 hour working day may be closer to reality but for consistency, eight hour working days are employed in this paper. This should not form an issue as long as this is made transparent.

27. Jerrad Lancaster, "Syracusan Settlement Expansion in South-Eastern Sicily in the Archaic Period" (PhD diss., Royal Holloway, University of London, London, 2017), 110.

28. Gallant, Risk and survival, 11, 21-27: emphasizing that households are in constant flux in terms of the dynamics of the life cycle and relating to time.

29. Abrams, Maya, table 2.

30. Gallant, Risk and survival; Abrams, Maya.

\section{8}




\section{Forces of the hands, forces of the lands}

31. Timonen, and Brysbaert, "Saving up for a rainy day", in the 13th c BCE period.

32. I suggest that maintaining a house is cheaper than building anew and that perhaps a house could, on average, be used for two generations of 25 years (see Gallant's, Risk and survival, 27, life cycle of 24 years). This would imply that in a century, a double amount of houses serving 20,000 people would need to be built.

33. Paul Halstead, Two oxen ahead. Pre-mechanized farming in the Mediterranean (Chichester: John Wiley and Sons, 2014), 109, 247-248.

34. By crop rotation; fallow land was only possible for larger landowners (based on Gallant, Risk and survival, 89).

35. Halstead, Two oxen ahead, 119.

36. Average plot size for named (well-to-do) individuals in Pylos tablets, see Dimitris Nakassis, Individuals and Society in Mycenaean Pylos (Leiden: Brill, 2013), 179.

37. Pulse reaping takes $0.05-0.06 \mathrm{ha} /$ person-days (Halstead, Two oxen ahead, 103), thus slower than cereals.

38. Grinding cost: Delwen Samuel, "Experimental grinding and ancient Egyptian flour production," in Beyond the Horizon: Studies in Egyptian Art, Archaeology, and History in Honour of Barry J. Kemp, ed. Salima Ikram, and Aidan Dodson (Cairo: American University in Cairo Press, 2010), 464.

39. 2 adults +3 children: after Gallant, Risk and survival, 18-19, 89 .

40. Elizabeth A. Mancz, "Examination of changing patterns of animal-husbandry of the late Bronze and Dark ages of Nichoria in the southwestern Peloponnese" (Unpublished PhD diss., Michigan: Ann Arbor, UMI Dissertation Services, 1989), 69-75, discusses the problems around quantifying faunal remains in context.

41. Gallant, Risk and survival, 33, 66-73, n. 4, table 4.2.

42. Halstead, Two oxen ahead, 182, table 4.1.

43. 150 and $200 / 12=12.5$ and 16.6 .

44. Gallant, Risk and survival, 66-73, table 4.2.

45. See also Gallant, Risk and survival, 92-94 for extra-household expenditures. He includes building timbers too but these are partially absorbed in the domestic house construction here.

46. E.g. Nakassis, Mycenaean Pylos, 21-27.

47. Nakassis, Mycenaean Pylos, 73-74.

48. Nakassis, Mycenaean Pylos, 26.

49. The most common visible artisanal remains found. This paper's length does not allow other crafts to be discussed in similar detail.

50. Eleni Hasaki, "The ancient Greek ceramic kilns and their contribution to the technology and organization of the potters' workshops," in Proceedings of the 2nd International Conference on Ancient Greek Technology, ed. Theodosis P. Tasios, and Clairy Palyvou (Athens: EMAET Chamber, 2006), 111; Peter Acton, Poiesis. Manufacturing in Classical Athens (Oxford: Oxford University Press, 2014), 92.

51. Small: av. $\mathrm{H}=10.8 \mathrm{~cm}$ and $\mathrm{W}=13.2 \mathrm{~cm}$; Medium: av. $\mathrm{H}=25 \mathrm{~cm}$ and $\mathrm{W}=15.3 \mathrm{~cm}$; Large wide: av. $\mathrm{H}=38.4 \mathrm{~cm}$ and $\mathrm{W}=32.5 \mathrm{~cm}$ (after Acton, Poiesis, 93, table 3.1).

52. Acton, Poiesis, 96.

53. Based on sizes given in Acton, Poiesis, 316 , table 3.1 and not stacking to full capacity: 


\section{Brysbaert}

Acton, Poiesis, 316, table 3.1. Before he halves this, Whitelaw's number per 8 hour working day arrives at 54 vessels: 12,000 in 1768 hours $=54$ in 8 hours, so very similar to my own estimates based on Acton's data; here I do not halve my numbers since the initial number based on Whitelaw fits well with that based on Acton. Whitelaw's potter works 300 days a year but also made stirrup jars which are not included here since they are palatial vessels, not domestic.

54. Todd Whitelaw, "Reading between the tablets: assessing Mycenaean palatial involvement in ceramic production and consumption," in Economy and Politics in the Mycenaean Palace States. Proceedings of a Conference held on 1-3 July 1999 in the Faculty of Classics, Cambridge (Cambridge Philological Society, suppl. Vol. 27), ed. Sofia Voutsaki, and John Killen (Cambridge: Cambridge Philological Society, 2001), 62 .

55. Whitelaw, "Tablets", 64.

56. Whitelaw, "Tablets", 61-67; Acton, Poiesis, 87-101.

57. Acton, Poiesis, 94.

58. See Table 3.

59. Sofia Voutsaki, "From the kinship economy to the palatial economy: the Argolid in the second millennium," in Political Economies of the Aegean Bronze Age. Papers from the Langford Conference, Florida State University, Tallahassee, 22-24 February 2007, ed. Daniel Pullen (Oxford: Oxbow Books, 2010a), 97, 100-104.

60. Elliot M. Abrams, and Thomas W. Bolland, "Architectural energetics, ancient monuments and operations management," Journal of Archaeological Method and Theory 6, no. 4 (December 1999), 264, 272, https://www.jstor.org/stable/20177407.

61. Brysbaert, "Socio-economic reflections," 80-81.

62. Eberhard Zangger, "Landscape changes around Tiryns during the Bronze Age," American Journal of Archaeology 98, no. 2 (1994): 210-212, DOI: 10.2307/506635.

63. Maran, "Tiryns," 729; Maran et al., "Tiryns, Griechenland. Die Arbeiten der Jahre 2015 bis 2018," E-Forschungsberichte des DAI (2019): 68-77, https://publications. dainst.org/journals/efb/2182/6595.

64. Birgitta L. Sjöberg, "Asine and the Argolid in the Late Helladic III Period. A socioeconomic Study", British Archaeological Reports, International Series 1225, (Oxford: Archaeopress, 2004), 140-41.

65. Klaus Kilian, "Earthquakes and Archaeological Context at 13th Century B.C. Tiryns," in Archaeoseismology (Fitch Laboratory Occasional Paper 7), ed. Stathis Stiros, and Richard E. Jones (Athens: IGME - Institute of Geology \& Mineral Exploration \& The British School at Athens, 1996), 63-68.

66. As argued by Kilian, "Earthquakes", 63-68; Katie Demakopoulou, and Nicoletta DivariValakou, "The fortifications of the Mycenaean acropolis of Midea," in POLEMOS. Le Context Guerrier en Egée à l'Age du Bronze. Actes de la 7e Rencontre égéenne internationale, Université de Liège, 14-17 Avril 1998, ed. Robert Laffineur (Liège and Texas: Université de Liège and University of Texas at Austin, 1999), 210; but see Klaus-G. Hinzen et al., "Testing the response of Mycenaean terracotta figurines and vessels to earthquake ground motions," Geoarchaeology. An International Journal 30, no. 1 (January/February 2015): 2-4, https://doi.org/10.1002/gea.21499. 
67. Sturt Manning, "Some perspectives on the frequency and significant, historically forcing drought and subsistence crises in Anatolia and the region," in Water and Power in Past Societies, IEMA Proceedings, Vol.7, ed. Emily Hold (Albany: State University of New York Press, 2018), 281; Maeve McHugh, The ancient Greek farmstead (Oxford: Oxbow Books, 2017), 8, 60, 158.

68. Peter Garnsey, Famine and food supply in the Graeco-roman world: responses to risk and crisis (Cambridge: Cambridge University Press, 1988), 17, table 3.

69. Paul Halstead, Two oxen ahead.

70. Garnsey, Famine, 6; crop failure in excess of two years in the Near East: Sarah K. Raphael, Climate and Political Climate: Environmental Disasters in the Medieval Levant (Brill: Leiden, 2013), 56.

71. Gallant, Risk and survival, 13.

72. Gallant, Risk and survival, 87.

73 . Dāmos, palace, religious sector: Susan M. Lupack, The Role of the Religious Sector in the Economy of Late Bronze Age Mycenaean Greece (Oxford: Archaeopress, 2008), 84-85; Julien Zurbach, Les hommes, la terre et la dette en Grèce (c. 1400-c. 500 a.C.): 2 volumes (Bordeaux: Maison Ausonius, 2017), 88-89, 129-44, 211.

74. Cynthia W. Shelmerdine, "Mycenaean palatial administration," in Ancient Greece from the Mycenaean Palaces to the Age of Homer, ed. Sigrid Deger-Jalkotzy, and Irene S. Lemos (Edinburgh: Edinburgh University Press. 2006), 75.

75. Gallant, Risk and survival, 87

76. Robin Osborne, Classical Landscapes with Figures: the ancient Greek city and its countryside (London: George Philip, 1987), 39.

77. Forbes, "Grand theories", 93-94; Halstead, Two oxen ahead, 162.

78. Halstead, Two oxen ahead, 158-59, 163.

79. Garnsey, Famine, 11.

80. Halstead, Two oxen ahead, 158, 180

81. Kostas S. Christakis, "Pithoi and food storage in Neopalatial Crete: a domestic perspective," World Archaeology 31, no. 1 (1999): 7-8, https://doi.org/10.1080/0043 8243.1999.9980429.

82. Halstead, Two oxen ahead, 110-12.

83. Garnsey, Famine, 13-14, 21.

84. See also Brysbaert, "Socio-economic reflections."

85. Halstead, Two oxen ahead, 175-77.

86. Also Daniel J. Pullen, "Ox and plow in the Early Bronze Age Aegean," American Journal of Archaeology 96, no. 1 (January 1992): 53, DOI: 10.2307/505757.

87. Halstead, Two oxen ahead, 181.

88. John O'Shea, "Coping with scarcity: exchange and social storage," in Economic Archaeology. Towards and Integration of Ecological and Social Approaches. (BAR-IS 96), ed. Alison Sheridan, and Geoff N. Bailey (Oxford: Archaeopress, 1981), 167-83; Pauline Wiessner, "Risk, reciprocity and social influences on Kung San economies," in Politics and History in Band Societies, ed. Eleanor Leacock, and Richard E. Lee (Cambridge: Cambridge University Press., 1982), 61-84.

89. Barrett P. Brenton, “The seasonality of storage," in Coping with Seasonal Constraints, 